\title{
Searching for Helicobacter pylori and Chlamydia pneumoniae in primary endodontic infections
}

Isabela N. Rôças'

José F. Siqueira Jr ${ }^{1}$

\section{ABSTRACT}

Objectives: The purpose of this study was to search samples from primary endodontic infections for the presence of two common human bacterial pathogens - Helicobacter pylori and Chlamydia pneumoniae.

Methods: Genomic DNA isolated from samples taken from 25 root canals of teeth with asymptomatic (chronic) apical periodontitis and 25 aspirates from acute apical abscess was initially amplified by the multiple displacement amplification approach and then used as template in species-specific polymerase chain reaction (PCR) for detection of H.pylori and C.pneumoniae.

Results: All clinical samples were positive for the presence of bacterial DNA. However, no clinical sample was positive for either H.pylori or C. pneumoniae.

Conclusions: Neither H. pylori nor C. pneumoniae were found in samples from primary endodontic infections. These findings suggest that these species are not candidate endodontic pathogens and that the necrotic root canal does not serve as a reservoir for these human pathogens in healthy patients. (Eur J Dent 2012;6:158-162)

Key words: Helicobacter pylori; Chlamydia pneumoniae; apical periodontitis; acute apical abscess; polymerase chain reaction

\section{INTRODUCTION}

Endodontic infections establish in root canals devoid of vital pulp tissue, which may occur because of pulp necrosis or pulp removal for treatment. The infection may spread locally to cause

1 Department of Endodontics and Molecular Microbiology Laboratory, Faculty of Dentistry, Estácio de Sá University, Rio de Janeiro, RJ, BRAZIL

- Corresponding author: Dr. José F. Siqueira Jr Faculty of Dentistry, Estácio de Sá University, Av. Alfredo Baltazar da Silveira, 580/cobertura, Recreio, Rio de Janeiro, 22790-710, RJ, BRAZIL

e-mail: jf_siqueiradyahoo.com; siqueiradestacio.br acute abscesses and the systemic implications of endodontic infections remain to be consistently investigated. ${ }^{1}$ Because the root canal devoid of pulp tissue is unable to mount an effective inflammatory defense against infection, the environment becomes conducive to the establishment of bacteria that are resident as well as transient in the oral cavity. Thus, the possibility exists that some important human pathogens may colonize the pulpless tooth.

Helicobacter pylori is a motile non-sporing microaerophilic curved or helical gram-negative rod that has been considered an important grastrointestinal 
pathogen. This species has been associated with gastritis and peptic ulcers, and may represent a risk factor for gastric cancer. ${ }^{2}$ It has been shown that approximately $50 \%$ of the world's population is infected with H. pylori. . $^{2-4}$ Overt clinical disease is found in about $5-10 \%$ of the infected individuals. ${ }^{5}$

Several researchers have suggested that the oral cavity may serve as the primary extragastric reservoir for $H$. pylori. ${ }^{6-14}$ Actually, $H$. pylori has been detected in samples from saliva, ${ }^{7,10,13,15-16}$ supragingival biofilms, ${ }^{8,16-17}$ subgingival biofilms, ${ }^{6-8,16}$ and tongue dorsum. ${ }^{16}$ At the time of writing, no study had yet investigated the occurrence of $H$. pylori in samples of endodontic origin.

Chlamydia pneumoniae is a spherical or ovoid obligately intracellular bacterial pathogen. This species is gram-negative in architecture and composition, with an outer membrane containing lypopolysaccharides. However, chlamydia apparently lacks peptidoglycan, even though genes for synthesis of this molecule have been identified in their genome. In the extracellular environment, chlamydiae occurs in an infective or dispersal form called elementary body, while within cells they exist in a replicative form called reticulate body. ${ }^{18}$ $C$. pneumoniae is one of the leading pathogens of community-acquired pneumonia, ${ }^{19}$ and has been associated with pharyngitis, sinusitis, and bronchitis. ${ }^{20}$ There is suggestive evidence that infection with this species and dental infections may be associated with atherosclerosis. ${ }^{21}$

C. pneumoniae has been rarely found to infect oral tissues. Tran et $\mathrm{al}^{22}$ used a species-specific $16 \mathrm{~S}$ rRNA gene-based polymerase chain reaction (PCR) identification method and did not find $C$. pneumoniae in any samples from subgingival biofilms from 50 adult patients with advanced marginal periodontitis. C. pneumoniae has been identified in the oropharynx, possibly involved with about $9 \%$ of cases of pharyngitis. ${ }^{23}$ Mantyla et al ${ }^{24}$ sought C. pneumoniae in subgingival biofilm samples from adults with marginal periodontitis and found this species in only one out of 12 patients using a quantitative PCR technique. To the best of our knowledge, only one previous study surveyed endodontic samples for the presence of $C$. pneumoniae. Nandakumar et $\mathrm{al}^{25}$ evaluated samples from primary and persistent/secondary endodontic infections of 40 patients for the presence of $C$. pneumoniae using single and nested PCR assays. Both methods failed to disclose $C$. pneumoniae in any of the endodontic samples examined.

If $H$. pylori and $C$. pneumonia are present in the oral cavity, both species might be able to survive in the necrotic root canal and then participate in the pathogenesis of apical periodontitis. Moreover, the necrotic root canal might act as a reservoir for these important human pathogens to exert systemic effects. The present study was undertaken to survey samples of primary endodontic infections from healthy patients for the presence of $H$. pylori and $C$. pneumoniae.

\section{MATERIALS AND METHODS}

The study protocol was approved by the Ethics Committee of the Estácio de Sá University, Rio de Janeiro, Brazil. Samples were taken from patients who had been referred for root canal treatment or emergency treatment to the Department of Endodontics, Estácio de Sá University. Only singlerooted teeth from adult patients lages ranging from 18 to 74 years), all of them having carious lesions, necrotic pulps and radiographic evidence of apical periodontitis, were included in this study. Selected teeth showed an absence of periodontal pockets deeper than $4 \mathrm{~mm}$. In general, 50 samples of primary endodontic infections were obtained: 25 asymptomatic cases diagnosed as chronic apical periodontitis and 25 cases diagnosed as acute apical abscesses, which showed pain and localized or diffuse swellings along with fever, lymphadenopathy, or malaise. No apparent communication from the abscess to the oral cavity or the skin surface was observed. Patients reported no gastric diseases and no other significant systemic condition. Patients who have taken antibiotics over the previous 3 months were excluded from the study.

In cases of chronic apical periodontitis, samples were obtained from the root canals using sterile paper points. After the tooth crown was cleansed with pumice, rubber dam was placed and the tooth and the surrounding field were cleansed with $3 \%$ hydrogen peroxide and disinfected with a $2.5 \% \mathrm{Na}-$ $\mathrm{OCl}$ solution. Caries was removed and the access cavity was prepared. The operative field, including the pulp chamber, was again swabbed with $2.5 \%$ $\mathrm{NaOCl}$, which was then inactivated by sterile $5 \%$ sodium thiosulphate. If the root canal was dry, a small amount of sterile saline solution was introduced into the canal. Samples were initially collected by 
means of a \#15 K-type file with the handle cut off. The file was introduced to a level approximately $1 \mathrm{~mm}$ short of the root apex, based on diagnostic radiographs, and a gentle filing motion was applied. Afterwards, two sequential paper points were placed to the same level and used to soak up the fluid in the canal. Each paper point was retained in position for $1 \mathrm{~min}$. The cut file and the two paper points were transferred to cryotubes containing $1 \mathrm{ml}$ of Tris-EDTA buffer $(10 \mathrm{mM}$ Tris- $\mathrm{HCl}, 1 \mathrm{mM}$ EDTA, pH 7.6) and immediately frozen at $-20^{\circ} \mathrm{C}$.

Abscesses were sampled by aspiration of purulent exudate from the swollen mucosa using a sterile syringe. The overlying mucosa was disinfected with $2 \%$ chlorhexidine, and a sterile disposable syringe was used to aspirate pus, which was immediately injected into cryotubes containing Tris-EDTA buffer. Pus samples were then immediately frozen.

DNA was extracted using the QIAamp DNA Mini Kit (Qiagen, Valencia, CA, USA) according to the manufacturer's instructions. DNA extracted from $H$. pylori ATCC 43629 and C. pneumoniae ATCC VR1310 served as positive controls.

DNA extracts from clinical samples and positive controls were subjected to multiple displacement amplification (MDA) by using the Illustra GenomiPhi V2 DNA Amplification kit (GE Healthcare, Piscataway, NJ, USAl following the manufacturer's instructions. A negative control with sterile ultrapure water instead of sample was included in every batch of MDA. This MDA step was carried out to achieve a better performance of the subsequent PCR assays, particularly for samples with low number of bacteria.

In order to check if bacterial DNA was available for analysis after extraction, aliquots of the amplified DNA extracts from clinical samples were evaluated by polymerase chain reaction (PCR) using a broad-range 16S rRNA gene primer set.

Primers and PCR cycling conditions used for broad-range analysis or specific detection of $H$. pylori and $C$. pneumoniae were as described previously. ${ }^{11,22,26}$ PCR amplifications were performed in a $50 \mu \mathrm{l}$ of reaction mixture containing $5 \mu \mathrm{l}$ of DNA extract, $0.8 \mu \mathrm{M}$ of each primer, $5 \mu \mathrm{l}$ of $10 \times$ PCR buffer (Fermentas, Burlington, Canada), $2 \mathrm{mM} \mathrm{MgCl}, 1.3 \mathrm{U}$ of Taq DNA polymerase (Fermentas) and $0.2 \mathrm{mM}$ of each deoxyribonucleoside triphosphate (dNTPs) (Biotools, Madrid, Spain). Positive control comprising DNA extracted from $H$. pylori and C. pneumoniae and negative controls consisting of sterile ultrapure water instead of sample were included with each batch of samples analyzed. DNA was amplified using a DNA thermocycler (Mastercycler personal, Eppendorff, Hamburg, Germany).

PCR products were subjected to electrophoresis in a $1.5 \%$ agarose gel-Tris-borate-EDTA buffer. The gel was stained with GelRed (Biotium, Hayward, CA, USA) and visualized under UV illumination. A 100bp DNA ladder (New England Biolabs, Beverly, MA) was used as a molecular size standard.

\section{RESULTS}

All genomic extracts from clinical samples exhibited the expected amplicon after PCR amplification with broad-range $16 \mathrm{~S}$ rRNA gene primers. This indicates that the DNA extraction and amplification procedures were adequate, bacteria were present in all examined samples, and significant PCR inhibitors were not present. No PCR products were observed in negative controls using sterile ultrapure water instead of sample. Positive controls yielded the amplicons of predicted sizes for each tested species. No clinical sample was positive for either $H$. pylori or C.pneumoniae.

\section{DISCUSSION}

To increase the sensitivity of the method, the present study made use of nonspecific whole genomic amplification by means of MDA so as to generate large quantity of assay-ready DNA. MDA is of special value in experiments involving samples with low amount of DNA and has been used as a prePCR strategy for the detection of low copy number sequences. ${ }^{27-28}$ This can be the case for endodontic infections, because of the recognized limitations of root canal sampling techniques. ${ }^{29-30}$

In the present study, endodontic samples were taken from healthy patients with no informed gastric infection and all samples were negative for $H$. pylori. Although the oral cavity has been suggested to be a reservoir for $H$. pylori, there appears to be no consensus in this regard. Prevalence of $H$. pylori in the oral cavity has been shown to range from $0 \%{ }^{31}$ to $97 \% .^{10}$ Specifically, detection of $H$. pylori in subgingival biofilms has also been demonstrated to vary, with studies showing absence ${ }^{32}$ and others finding this species in about $25-40 \%$ of the samples. ${ }^{7-9,11}$ A study concluded that the oral cavity may not be a reservoir for $H$. pylori in patients with 
epigastric pain syndrome, with the bacterium being detected exclusively in the stomach. ${ }^{33}$ Even so, it remains to be evaluated if this bacterial species occurs in necrotic root canals from patients with established gastric infection.

C. pneumoniae was not detected in any endodontic samples either. As for its occurrence in the oral cavity, there are fewer reports as compared to $H$. pylori and data, while somewhat inconclusive, suggest that this species is not a common oral inhabitant. Tran et $\mathrm{al}^{22}$ did not detect $C$. pneumoniae in the subgingival dental plaque, whereas Huovinen et a ${ }^{23}$ identified it in oropharynx. Mantyla et al ${ }^{24}$ detected C. pneumoniae RNA in the subgingival plaque samples from only 1 of 12 patients tested. Similar to the present study, Nandakumar et $\mathrm{al}^{25}$ did not find this species in samples from primary and persistent/ secondary endodontic infections using two sensitive molecular methods.

Bacteria colonizing the necrotic root canal are usually members of the oral microbiota. ${ }^{34}$ Absence of both target species in endodontic samples may indicate that either they are not commonly present in the oral cavity or that the root canal environmental conditions are not conducive to their establishment. The former is in agreement with some studies mentioned above that reported absence or low prevalence of these species in the oral cavity. The latter may be related, for instance, to ecological conditions established by bacterial interactions in the endodontic bacterial community. Future studies investigating the concomitant presence of these species in saliva or dental plaque and root canal infections may help elucidate these questions.

In any circumstance, our findings make it reasonable to conclude that $H$.pylori and $C$. pneumoniae are not candidate endodontic pathogens and that the necrotic root canal does not serve as a reservoir for these two important human pathogens.

\section{ACKNOWLEDGEMENTS}

This study was supported by grants from Conselho Nacional de Desenvolvimento Científico e Tecnológico (CNPq), and Fundação Carlos Chagas Filho de Amparo à Pesquisa do Estado do Rio de Janeiro (FAPERJ), Brazilian Governmental Institutions.

\section{REFERENCES}

1. Fouad AF. Endodontic infections and systemic disease. In: Fouad AF, ed. Endodontic microbiology. Ames, lowa: WileyBlackwell, 2009: 320-338.

2. Nguyen TN, Barkun AN, Fallone CA. Host determinants of Helicobacter pylori infection and its clinical outcome. Helicobacter 1999;4:185-197.

3. Shi R, Xu S, Zhang $H$, Ding $Y$, Sun G, Huang $X$, Chen $X, L i$ $X$, Yan Z, Zhang G. Prevalence and risk factors for Helicobacter pylori infection in Chinese populations. Helicobacter 2008;13:157-165.

4. Megraud F, Brassens-Rabbe MP, Denis F, Belbouri A, Hoa $D Q$. Seroepidemiology of Campylobacter pylori infection in various populations. J Clin Microbiol 1989;27:1870-1873.

5. Peek RMJ, Blaser MJ. Helicobacter pylori: pathogenesis of a "slow" bacterial infection. In: Schaechter M, Engleberg NC, Eisenstein BI, Medoff G, eds. Mechanisms of microbial disease. 3rd ed. Baltimore: Williams \& Wilkins, 1998: 224229

6. de Souza Goncalves L, Souto R, Colombo AP. Detection of Helicobacter pylori, Enterococcus faecalis, and Pseudomonas aeruginosa in the subgingival biofilm of HIV-infected subjects undergoing HAART with chronic periodontitis. Eur J Clin Microbiol Infect Dis 2009;28:1335-1342.

7. Souto R, Colombo AP. Detection of Helicobacter pylori by polymerase chain reaction in the subgingival biofilm and saliva of non-dyspeptic periodontal patients. J Periodontol 2008;79:97-103

8. Gebara EC, Pannuti C, Faria CM, Chehter L, Mayer MP, Lima LA. Prevalence of Helicobacter pylori detected by polymerase chain reaction in the oral cavity of periodontitis patients. Oral Microbiol Immunol 2004;19:277-280.

9. Dye BA, Kruszon-Moran D, McQuillan G. The relationship between periodontal disease attributes and Helicobacter pylori infection among adults in the United States. Am J Public Health 2002;92:1809-1815.

10. Song Q, Lange T, Spahr A, Adler G, Bode G. Characteristic distribution pattern of Helicobacter pylori in dental plaque and saliva detected with nested PCR. J Med Microbiol 2000;49:349-353.

11. Riggio MP, Lennon A. Identification by PCR of Helicobacter pylori in subgingival plaque of adult periodontitis patients. J Med Microbiol 1999;48:317-322.

12. Oshowo A, Gillam D, Botha A, Tunio M, Holton J, Boulos P, Hobsley M. Helicobacter pylori: the mouth, stomach, and gut axis. Ann Periodontol 1998;3:276-280.

13. Ferguson DA, Jr., Li C, Patel NR, Mayberry WR, Chi DS, Thomas E. Isolation of Helicobacter pylori from saliva. $J$ Clin Microbiol 1993;31:2802-2804. 
14. Nguyen AM, Engstrand L, Genta RM, Graham DY, el-Zaatari FA. Detection of Helicobacter pylori in dental plaque by reverse transcription-polymerase chain reaction. J Clin $\mathrm{Mi}$ crobiol 1993;31:783-787.

15. Mapstone NP, Lynch DA, Lewis FA, Axon AT, Tompkins DS, Dixon MF, Quirke P. Identification of Helicobacter pylori DNA in the mouths and stomachs of patients with gastritis using PCR. J Clin Pathol 1993;46:540-543.

16. Umeda M, Kobayashi H, Takeuchi Y, Hayashi J, MorotomeHayashi Y, Yano K, Aoki A, Ohkusa T, Ishikawa I. High prevalence of Helicobacter pylori detected by PCR in the oral cavities of periodontitis patients. J Periodontol 2003; 74: 129-134.

17. Kignel S, de Almeida Pina F, Andre EA, Alves Mayer MP, Birman EG. Occurrence of Helicobacter pylori in dental plaque and saliva of dyspeptic patients. Oral Dis 2005;11:17-21.

18. Ward ME, Ridgway G. Chlamydia. In: Collier L, Balows A, Sussman M, eds. Topley \& Wilson's microbiology and microbial infections. Vol 2, Systematic bacteriology. 9th ed. London: Arnold, 1998: 1331-1346.

19. Miyashita N, Saito A, Kohno S, Oizumi K, Yamaguchi K, Watanabe A, Oda H, Fukano H, Yoshida K, Niki Y, Matsushima T. Community-acquired Chlamydia pneumoniae pneumonia in Japan: a prospective multicenter community-acquired pneumonia study. Intern Med 2002;41:943-949.

20. Grayston JT, Aldous MB, Easton A, Wang SP, Kuo CC, Campbell LA, Altman J. Evidence that Chlamydia pneumoniae causes pneumonia and bronchitis. I Infect Dis 1993; 168:1231-1235.

21. Valtonen VV. Role of infections in atherosclerosis. Am Heart $J$ 1999;138:S431-433.

22. Tran T, Flynn MJ, Chen C, Slots J. Absence of Porphyromonas asaccharolytica, Bacteroides fragilis and Chlamydia pneumoniae in human subgingival plaque. Oral Microbiol Immunol 1997; 12:377-378.

23. Huovinen $P$, Lahtonen R, Ziegler T, Meurman O, Hakkarainen K, Miettinen A, Arstila P, Eskola J, Saikku P. Pharyngitis in adults: the presence and coexistence of viruses and bacterial organisms. Ann Intern Med 1989;110:612-616.

24. Mantyla $P$, Stenman M, Paldanius M, Saikku $P$, Sorsa T, Meurman JH. Chlamydia pneumoniae together with collagenase-2 (MMP-8) in periodontal lesions. Oral Dis $2004 ; 10: 32-35$.

25. Nandakumar R, Whiting J, Fouad AF. Identification of selected respiratory pathogens in endodontic infections. Oral Surg Oral Med Oral Pathol Oral Radiol Endod 2008;106:145151.
26. Ashimoto A, Chen C, Bakker I, Slots J. Polymerase chain reaction detection of 8 putative periodontal pathogens in subgingival plaque of gingivitis and advanced periodontitis lesions. Oral Microbiol Immunol 1996;11:266-273.

27. Gonzalez JM, Portillo MC, Saiz-Jimenez C. Multiple displacement amplification as a pre-polymerase chain reaction (pre-PCR) to process difficult to amplify samples and low copy number sequences from natural environments. Environ Microbiol 2005;7:1024-1028.

28. Grover A, Azmi W, Paul Khurana SM, Chakrabarti SK. Multiple displacement amplification as a pre-polymerase chain reaction (pre-PCR) to detect ultra low population of Ralstonia solanacearum (Smith 1896) Yabuchi et al. (1996). Lett Appl Microbiol 2009;49:539-543.

29. Sathorn C, Parashos P, Messer HH. How useful is root canal culturing in predicting treatment outcome? J Endod 2007;33:220-225.

30. Siqueira JF, Jr, Rôças IN. Polymerase chain reaction-based analysis of microorganisms associated with failed endodontic treatment. Oral Surg Oral Med Oral Pathol Oral Radiol Endod 2004;97:85-94.

31. Martinez-Gomis J, Diouf A, Lakhssassi N, Sixou M. Absence of Helicobacter pylori in the oral cavity of 10 non-dyspeptic subjects demonstrated by real-time polymerase chain reaction. Oral Microbiol Immunol 2006;21:407-410.

32. Asikainen S, Chen C, Slots J. Absence of Helicobacter pylori in subgingival samples determined by polymerase chain reaction. Oral Microbiol Immunol 1994;9:318-320.

33. Silva Rossi-Aguiar VP, Navarro-Rodriguez T, Mattar R, Siqueira de Melo Peres MP, Correa Barbuti R, Silva FM, Carrilho FJ, Eisig JN. Oral cavity is not a reservoir for Helicobacter pylori in infected patients with functional dyspepsia. Oral Microbiol Immunol 2009;24:255-259.

34. Siqueira JF, Jr., Rôças IN. Diversity of endodontic microbiota revisited. J Dent Res 2009;88:969-981. 